\title{
REDUCING THE LIKELIHOOD OF ELECTRICAL POWER-RELATED DISASTERS: A FUZZY MCDM APPROACH
}

\author{
Eko Setiawan \\ Industrial Engineering Department, Engineering Faculty \\ Universitas Muhammadiyah Surakarta - Indonesia \\ Email: Eko.Setiawan@ums.ac.id \\ Septin Puji Astuti \\ Centre for Science and Technology \\ IAIN Surakarta - Indonesia \\ Email: septin.astuti@iain-surakarta.ac.id \\ Handoko \\ Industrial Engineering Department, Engineering Faculty \\ Universitas Muhammadiyah Surakarta - Indonesia
}

\begin{abstract}
ABSTRAK
Many of disasters are related to electrical power systems. They affect human life and economy. In order to reduce the negative impacts caused by the failure of electricity power system due to disasters and to create a robust electrical power system, selecting the best relay of electricity power is a must. This study identified the best protective relay of electrical power systems of PLN in Surakarta region by applying analytic hierarchy process (AHP), one of MCDM approaches, combined with fuzzy logic. Extent analysis approach was implemented to derive priorities of various criteria, sub-criteria and alternatives. Three relays being considered in the selection process are electromagnetic relay, digital relay and static relay. Four criteria in this study are techno-economy, fault frequency, protection of transmission line and advantage of relay over others. Meanwhile, five sub-criteria for each criterion are reliability, selectivity, sensitivity, working speed and efficient. Based on the criteria and sub-criteria, it can be inferred that in terms of four working areas of PLN management in Surakarta region, digital relay is seen as the best choice of relays.
\end{abstract}

Kata kunci: disaster likelihood, electricity disruption, fuzzy AHP, protective systems.

\section{INTRODUCTION}

Disasters happen in an increasing trend. They affected various aspects of human beings and their communities, threatened individuals' life, caused tens of thousands of deaths and created billion US dollar losses [1]. Many of the disasters are related to electrical power system has been studied by scholars (e.g. [2-5]. Electrical power system is highly open to extreme climatic events due to its vital existence in the overall socioeconomic networks [6]. Failures of electrical power systems or networks impose social and economical problems [2]. These all lead to the need of having a more robust electrical power system.

Research on electrical power problems in association with disasters is abundant. This includes effect of natural disasters to Critical Infrastructure Sectors (CIS) in the United States (US) such as infrastructures of telecommunication, power, water, and sewage [8], effects of electricity disruption resulted from extreme climatic arrivals on socioeconomic systems in China compared to those in Japan [6], impacts of power distribution systems destructed by hurricanes on economy [9], failure of transmission network of electric power systems following earthquakes [2], and pre-event recovery planning to restore lifeline infrastructures following a major disruptive disaster [10]. It is also found that electrical power system breakdown itself is seen as a disaster $[4,11]$.

Acknowledging the strategic position of electrical power-related breakdown, research on its detection, analysis, and prevention is seen as crucial [12-14]. Important roles of protective relays in particular are also inviting for scholars to pay attention to. For example, reviews the important concepts of reliability theory that will form a basis for analysing protective system analysis [15]. An adaptive procedure as a manifestation of the role of protective relays in assuring continuous service in the power system, in the meantime, is proposed [16]. Problem of resource allocation with relays operated in multicarrier scenarios is addressed in [17] followed by a proposal of advanced resource coordination procedures for the problem. In the meantime, present a computational means for automatically determining adjustments of all protection 
devices in power distribution networks to get the best technical application, making its performance optimized and making easier studies on electrical power protection [18].

It is frequent that the need of having a more robust electrical power system takes place in a group decision-making environment and requires various variables and factors taken into consideration (e.g. [7]). It is also evident that people's view about things is sometimes vague or blurred in nature. By taking all of these factors into consideration, the paper proposes a selection of the best protective relay, a crucial component of electrical protection systems, by using an analytic hierarchy process (AHP), one of multiple criteria decision making (MCDM) approaches, combined with fuzzy logic.

Multiple Criteria Decision Making (MCDM) approaches have been proposed by many researchers in order to address the electrical power-related problems. Analytic Hierarchy Process (AHP) combined with fuzzy set theories has been applied for improving cost effectiveness of power distribution maintenance policies [19]. Five criteria considered in the study are number of components, component failures, repair duration, investment cost and maintenance cost. Meanwhile, AHP and entropy method for establishing index system of safety benefit of power supply enterprise has been utilised as well [20]. A new possibilistic (fuzzy) model was also applied for the multiobjective optimal planning of power distribution networks [21]. Nonlinear Integer Programming (NLIP) model with binary variables was applied for a problem of protective device allocation in the main feeder and all branches of an overhead distribution circuit [22]. Mixed Integer Non-Linear Programming (MINLP) with real and binary variables was used for problem of optimised placement of control and protective devices in distribution networks [22]. Multiobjective Ant Colony Optimization (MACO) was used to optimally place switches and protective devices in electric power distribution networks [23]. A new fuzzy multi-criteria decision making algorithm was applied for proper processing of information sources available at the utilities in the context of distribution network reconfiguration [7]. The application of a technique based on Nondominated Sorting Genetic Algorithm-II (NSGA-II) was implemented for solving the service restoration problem in an electric power distribution system [24].

This paper is presented in the following order. The need of having a more robust electrical power system assuming disaster likelihood is provided first in Introduction. Relevant research papers are subsequently reviewed and presented in the next section. An example of protective relay selection by using fuzzy AHP approach is provided in section 3 of the paper. The paper concludes with future research direction.

\section{RESEARCH METHODOLOGY}

One major element of an electrical power system is a protective system of which crucial component is a protective relay. Protective relays are expected to operate soon at the presence of electrical disturbances [25]. Protective relays are put in place in order to recognize any abnormal conditions in electrical power networks and take the required measures to localize the part of the circuit operating under those irregular circumstances [26, 27]. Obtaining the best protective relays for certain electrical power system is, therefore, extremely important.

The study was conducted in PT Perusahaan Umum Listrik Negara (PLN), Surakarta region. Four criteria and five sub-critera to select best protective relay were taken from interview and combined with [28]. The hierarchy of criteria and sub-criteria for selecting the best protective relay is provided in Figure 1. In order to select the best protective relay among three alternative protective relays, i.e. electromagnetic relay, digital relay and static relay, four criteria and five sub-criteria are put in place.

Four criteria to select best protective relay which were applied in this study are techno-economy, fault frequency, the importance of protected transmission line and advantages of the relay over other relay. Techno-economy is the criteria of best protective relay based on the advantage of technology and economy point of view. Meanwhile, fault frequency criteria has close relation to number of fault of protective relay. It has relation to reliability of protective relay. Protective relay influences safety and I has relation to protected transmission line. Hence, ths criteria is importance in selecting best protective relay. The last criteria is the advantages of relay over other relay which may be measured subjectively from expert point of view. 


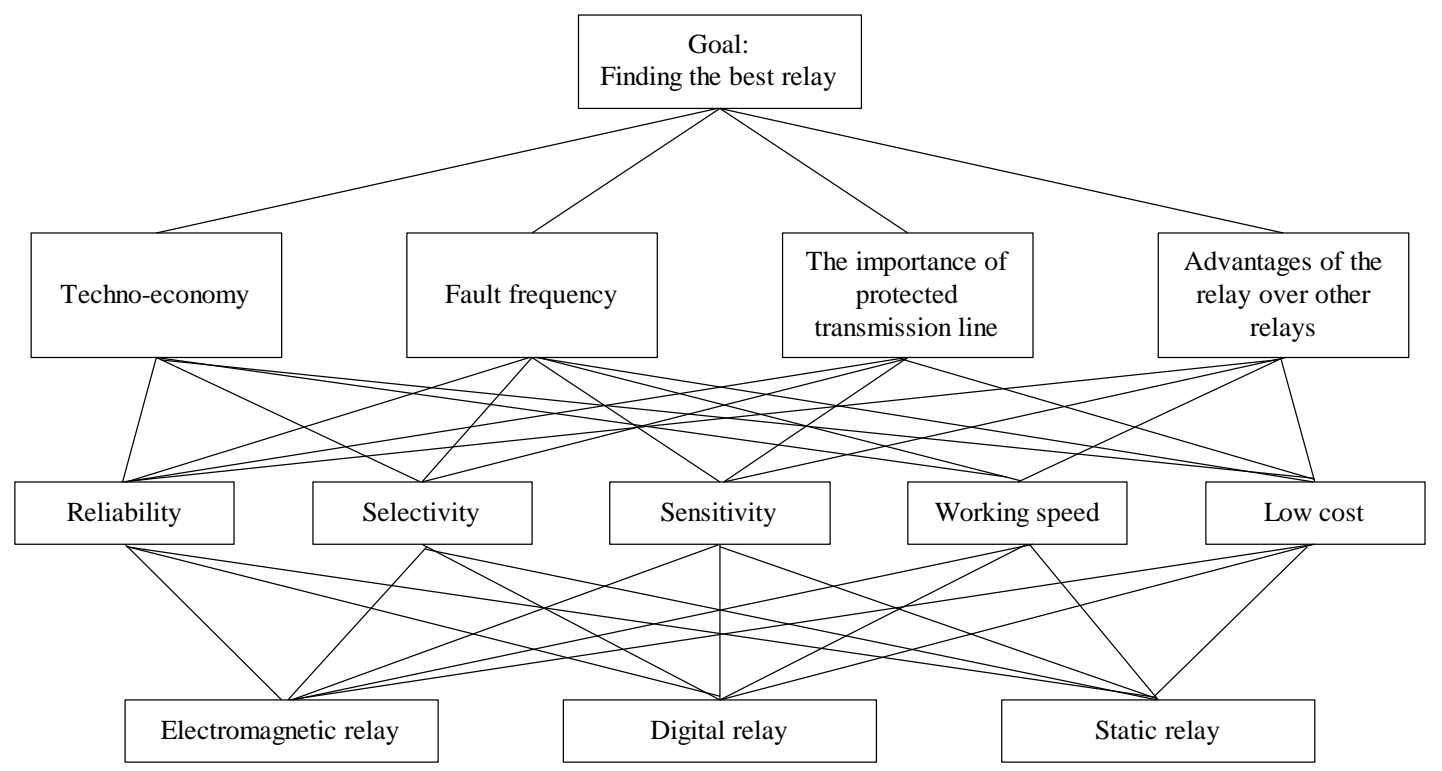

Figure 1. The Hierarchy For Selecting The Best Relay

Meanwhile, the five sub-criteria which is applied in this study were reliability, selectivity, sensitivity, working speed and low cost. At the same time, the safety relays in this study are selected based on distribution system in Surakarta. Reliability in this case means that protective relay is able to work well. Selectivity means the relay is able to identify the fault in distribution line. Sensitivity of relay means that the relay is sensitive to minimum capacity. Working speed of relay means that the relay is able to work fast under critical clearing time and no more than $10 \mathrm{~ms}$. The last sub-criteria, low cost which, means that the relay cost is under budget price.

In order to select best protective relay, four areas of relay was selected to represent Surakarta area. Those area are Jajar which representing the centre of Surakarta, Banyudono which representing northwestern part of Surakarta, Palur which representing north-eastern part of Surakarta and Wonogiri which representing southern part of Surakarta.

Decision method for selecting the best protective relay is fuzzy analytic hierarchy process (fuzzy AHP) by using extent analysis approach [29]. Membership function is triangular fuzzy number (TFN). Beta distribution approach is applied for testing the consistency in order to calculate crisp value of multiple comparisons [30]. Additionally, linguistic scale and fuzzy triangular proposed by Perçin [29], as presented in Table 1, is applied in this study to assess the comparison between the criteria and sub-criteria. Table 2 shows the conversion of fuzzy scale and reciprocal fuzzy.

Table 1. Level of importance, fuzzy scale and reciprocal fuzzy applied in [29]

\begin{tabular}{lcc}
\hline \multicolumn{1}{c}{ Scale } & \\
\hline $\begin{array}{c}\text { Linguistic scale } \\
\text { (level of importance) }\end{array}$ & $\begin{array}{c}\text { Scale of fuzzy } \\
\text { triangular }\end{array}$ & $\begin{array}{c}\text { Reciprocal scale of } \\
\text { fuzzy triangular }\end{array}$ \\
\hline Equally important $(\mathrm{EI})$ & $(1 / 2,1,3 / 2)$ & $(2 / 3,1,2)$ \\
Weakly more important $(\mathrm{WMI})$ & $(1,3 / 2,2)$ & $(1 / 2,2 / 3,1)$ \\
Strongly more important $(\mathrm{SMI})$ & $(3 / 2,2,5 / 2)$ & $(2 / 5,1 / 2,2 / 3)$ \\
Very strongly more important $(\mathrm{VSMI})$ & $(2,5 / 2,3)$ & $(1 / 3,2 / 5,1 / 2)$ \\
Absolutely more important $(\mathrm{AMI})$ & $(5 / 2,3,7 / 2)$ & $(2 / 7,1 / 3,2 / 5)$ \\
\hline
\end{tabular}


Table 2. Linguistic scale conversion to questionnaire and the meaning of fuzzy scale

\begin{tabular}{|c|c|c|c|}
\hline Linguistic scale & $\begin{array}{c}\text { Scale for } \\
\text { questionnaire }\end{array}$ & $\begin{array}{c}\text { Scale of } \\
\text { fuzzy } \\
\text { triangular }\end{array}$ & $\begin{array}{l}\text { Reciprocal scale of } \\
\text { fuzzy triangular }\end{array}$ \\
\hline Equally important (EI) & 1 (middle) & $(1 / 2,1,3 / 2)$ & $(2 / 3,1,2)$ \\
\hline Weakly more important (WMI) & $\begin{array}{l}2 \text { (right) } \\
2 \text { (left) }\end{array}$ & $(1,3 / 2,2)$ & $(1 / 2,2 / 3,1)$ \\
\hline Strongly more important (SMI) & $\begin{array}{c}3 \text { (right) } \\
3 \text { (left) }\end{array}$ & $(3 / 2,2,5 / 2)$ & $(2 / 5,1 / 2,2 / 3)$ \\
\hline Very strongly more important (VSMI) & $\begin{array}{l}4 \text { (right) } \\
4 \text { (left) }\end{array}$ & $(2,5 / 2,3)$ & $(1 / 3,2 / 5,1 / 2)$ \\
\hline Absolutely more important (AMI) & $\begin{array}{c}5 \text { (right) } \\
5 \text { (left) }\end{array}$ & $(5 / 2,3,7 / 2)$ & $(2 / 7,1 / 3,2 / 5)$ \\
\hline
\end{tabular}

Defuzzification to crisp value in this study is conducted by using beta distribution. Let $M=(l, m, u)$ denotes triangular fuzzy number. Defuzzification of the number into crisp value is presented in equation 1.

$M \_$crisp $=(4 m+l+u) / 6$

Equation for calculating Consistency Index $(C I)$ and Consistency Ratio (CR) of multiple comparisons is presented in equation 2 and equation 3.

$$
\begin{aligned}
& C I=\left(\lambda_{\max }-n\right) /(n-1) \\
& C R=C I / R I
\end{aligned}
$$

where $\lambda_{\max }$ is the highest eigenvalue of defuzzified multiple comparison matrix, $n$ is number of element under comparison, $C I$ is consistency index, $C R$ is consistency ratio and $R I$ is random index. $R I$ for every element is presented in Table 3. If $C R$ value is equal or less than 10 per cent, the judgment of multiple comparisons is consistent.

Table 3. $R I$ according to Kwong \& Bai [30]

\begin{tabular}{c|c|c|c|c|c|c|c}
\hline $\boldsymbol{N}$ & $\mathbf{3}$ & $\mathbf{4}$ & $\mathbf{5}$ & $\mathbf{6}$ & $\mathbf{7}$ & $\mathbf{8}$ & $\mathbf{9}$ \\
\hline $\boldsymbol{R I}(\boldsymbol{n})$ & 0.58 & 0.9 & 1.12 & 1.24 & 1.32 & 1.41 & 1.45 \\
\hline
\end{tabular}

\section{ANALYSIS FOR PROTECTIVE RELAY SELECTION}

Table 4 presents consistency test of multiple comparisons, whilst Table 5 shows global weight of criteria, sub-criteria and alternatives. All $C R$ values in Table 4 show that all multiple comparisons among criteria and sub criteria from experts are consistent. Meanwhile, the global weight values of each criterion (see Table 5) of every location are not significantly different. Despite the distance between areas that contributes to different characteristic of GI-feeders, the experts argue that each location has a degree of importance similar to the other locations. This indicates that the experts view that location is irrelevant in selecting the most preferred protective relays. Global weights of all area, i.e. Jajar, Banyudono, Palur and Wonogiri of criteria fault of frequency and the importance of protected transmission line are similar. Meanwhile, the global weight among all area of techno-economy and advantages of the relay over other relays criteria are not significantly different. However, experts view that the advantages of the relay over other relays are the least important in selecting best protective relay in comparison to other criteria such as techno-economy, fault frequency and the protected of transmission line.

Likewise, global weights or level of importance of each sub-criterion in every area are different. Level of important of the criteria of reliability and selectivity in Jajar is the highest among other location. This is because Jajar relay station is the centre of Surakarta. Reliability and selectivity of protective relay in identifying fault is important. Even though this study resulted different level of important among subcriteria, there is similar conclusion that reliability and selectivity are two sub-criteria those have highest level of important in all location of relay station. 
Table 4. Consistency test

\begin{tabular}{|c|c|c|c|c|c|c|c|c|}
\hline \multirow{3}{*}{ Multiple comparison } & \multicolumn{8}{|c|}{ Location } \\
\hline & \multicolumn{2}{|c|}{ Jajar } & \multicolumn{2}{|c|}{ Banyudono } & \multicolumn{2}{|c|}{ Palur } & \multicolumn{2}{|c|}{ Wonogiri } \\
\hline & CR value & Note & CR value & Note & CR value & Note & CR value & Note \\
\hline Goal: best relay & 0.04 & Consistent & 0.04 & Consistent & 0.04 & Consistent & 0.04 & Consistent \\
\hline Criterion: Techno-economy & 0.03 & Consistent & 0.03 & Consistent & 0.03 & Consistent & 0.03 & Consistent \\
\hline Criterion: Fault frequency & 0.05 & Consistent & 0.07 & Consistent & 0.07 & Consistent & 0.07 & Consistent \\
\hline $\begin{array}{l}\text { Criterion: The importance of } \\
\text { transmission line protected }\end{array}$ & 0.05 & Consistent & 0.05 & Consistent & 0.07 & Consistent & 0.07 & Consistent \\
\hline $\begin{array}{c}\text { Criterion: Advantages of the relay } \\
\text { over other relays }\end{array}$ & 0.05 & Consistent & 0.05 & Consistent & 0.09 & Consistent & 0.07 & Consistent \\
\hline Sub-criterion: Reliabity & 0.06 & Consistent & 0.05 & Consistent & 0.05 & Consistent & 0.05 & Consistent \\
\hline Sub-criterion: Selectivity & 0.05 & Consistent & 0.04 & Consistent & 0.07 & Consistent & 0.07 & Consistent \\
\hline Sub-criterion: Sensitivity & 0.05 & Consistent & 0.05 & Consistent & 0.06 & Consistent & 0.06 & Consistent \\
\hline Sub-criterion: Working speed & 0.05 & Consistent & 0.04 & Consistent & 0.07 & Consistent & 0.07 & Consistent \\
\hline Sub-criterion: Low cost & 0.02 & Consistent & 0.05 & Consistent & 0.07 & Consistent & 0.07 & Consistent \\
\hline
\end{tabular}

Table 5. Global weight

\begin{tabular}{|c|c|c|c|c|c|}
\hline \multirow{2}{*}{\multicolumn{2}{|c|}{ Criterion/sub-criterion/alternative }} & \multicolumn{4}{|c|}{ Global weight } \\
\hline & & Jajar & Banyudono & Palur & Wonogiri \\
\hline \multirow{5}{*}{ Criterion } & Techno-economy & 0.30 & 0.30 & 0.30 & 0.29 \\
\hline & Fault frequency & 0.29 & 0.29 & 0.29 & 0.29 \\
\hline & The importance of transmission line protected & 0.29 & 0.29 & 0.29 & 0.29 \\
\hline & Advantages of the relay over other relays & 0.12 & 0.13 & 0.12 & 0.14 \\
\hline & Reliability & 0.10 & 0.08 & 0.08 & 0.07 \\
\hline \multirow{4}{*}{$\begin{array}{c}\text { Sub- } \\
\text { criterion }\end{array}$} & Selectivity & 0.10 & 0.08 & 0.08 & 0.07 \\
\hline & Sensitivity & 0.02 & 0.03 & 0.03 & 0.04 \\
\hline & Working speed & 0.01 & 0.03 & 0.03 & 0.04 \\
\hline & Low cost & 0.08 & 0.08 & 0.08 & 0.07 \\
\hline \multirow{3}{*}{$\begin{array}{l}\text { Alternati } \\
\text { ve }\end{array}$} & Electromagnetic relay & 0.24 & 0.30 & 0.26 & 0.33 \\
\hline & Static relay & 0.00 & 0.00 & 0.00 & 0.00 \\
\hline & Digital relay & 0.76 & 0.70 & 0.74 & 0.67 \\
\hline
\end{tabular}


Raliability of protective relays related to how well the protective relay work while selectivity means how well protective relay able to identify the fault in distribution line. This is important to guarantee electricity system work well. In additioj tho those sub-criteria, low cost is one of important sub-criteria as availability of fund is prominent. But it doesn't the only important criteria as the decision makers should consider reliability and selectivity. Meanwhile, sensitivity and working speed are two criterion those are least importance over other sub-criteria.

Finally, among three relays under considered, there is a strong indication that digital relay has the highest weight and static relay has the lowest weight. This strong indication is in line with what we have seen nowadays that digital relay is a common power system protection used. This result is also linear with that of [31] who found that, in Korea, about $90 \%$ of relays are digital ones.

\section{CONCLUSION AND FUTURE RESEARCH DIRECTION}

The application of a fuzzy AHP approach to protective relay selection shows that digital relay is the preferred relay over the other two relays. Despite lack of generality - due to the reason that there are five other areas in the region not included in the analysis -, the paper shows another applicability of MCDM approaches in response to electrical power-related disaster problems. This indicates that MCDM approaches are very potential in giving aid to solving electrical power-related disaster problems.

\section{ACKNOWLEDGMENT}

The authors would like to acknowledge Directorate General of Higher Education, Ministry of Research, Technology, and Higher Education, Republic of Indonesia for the funding support of the research project entitled Pemilihan Relay Pengaman di dalam Sistem Distribusi Tenaga Listrik Menggunakan Kriteria Majemuk [Project Number 188/SP2H/PP/DP2M/III/2008].

\section{REFERENCES}

[1] Bjarnadottir S, Li Y, Stewart MG. Risk-based economic assessment of mitigation strategies for power distribution poles subjected to hurricanes. Struct Infrastruct Eng 2014; 10: 740-752.

[2] Shinozuka M, Dong X, Chen TC, et al. Seismic performance of electric transmission network under component failures. Earthq Eng Struct Dyn 2007; 36: 227-244.

[3] Luo Q, He X, Mao B, et al. Research on power emergency caused by different types of disasters. 3rd Int Conf Mech Eng Intell Syst (ICMEIS 2015) 2015; 151-155.

[4] Rose A, Oladosu G, Liao SY. Business interruption impacts of a terrorist attack on the electric power system of Los Angeles: Customer resilience to a total blackout. Risk Anal 2007; 27: 513-531.

[5] Moore M. Case study: Electrical disaster recovery operations for a hospital. IEEE IAS Electr Saf Work $2013 ; 69-76$.

[6] Fan JL, Liang QM, Liang XJ, et al. National vulnerability to extreme climatic events: The cases of electricity disruption in China and Japan. Nat Hazards 2014; 71: 1937-1956.

[7] Bernardon DP, Garcia VJ, Ferreira ASQ, et al. Electric distribution network reconfiguration based on a fuzzy multi-criteria decision making algorithm. Electr Power Syst Res 2009; 79: 1400-1407.

[8] Chopra SS, Khanna V. Interconnectedness and interdependencies of critical infrastructures in the US economy: Implications for resilience. Phys A Stat Mech its Appl 2015; 436: 865-877.

[9] Salman AM, Li Y, Stewart MG. Evaluating system reliability and targeted hardening strategies of power distribution systems subjected to hurricanes. Reliab Eng Syst Saf 2015; 144: 319-333.

[10] Zorn CR, Shamseldin AY. Post-disaster infrastructure restoration: A comparison of events for future planning. Int J Disaster Risk Reduct 2015; 13: 158-166.

[11] Jin S, Jeong S, Kim J, et al. A logistics model for the transport of disaster victims with various injuries and survival probabilities. Ann Oper Res 2015; 230: 17-33. 
[12] Kezunovic M. Use of intelligent techniques for analysis of faults and protective relay operations. 2007 IEEE Power Eng Soc Gen Meet PES 2007; 3128: 1-3.

[13] Pang C, Kezunovic M. Detection tools for disturbances and protective relay operations leading to cascading events. 2009 IEEE Power Energy Soc Gen Meet PES ’09 2009; 1-6.

[14] Zhang N, Kezunovic M. A real time fault analysis tool for monitoring operation of transmission line protective relay. Electr Power Syst Res 2007; 77: 361-370.

[15] Beshir ME. Failure modes and reliability modeling of protective systems. Appl Energy 1989; 34: 3546.

[16] Calderaro V, Galdi V, Piccolo A, et al. Adaptive relays for overhead line protection. Electr Power Syst Res 2007; 77: 1552-1559.

[17] Góra J, Redana S. Resource management issues for multi-carrier relay-enhanced systems. EURASIP J Wirel Commun Netw 2012; 2012: 124.

[18] Comassetto L, Bernardon DP, Canha LN, et al. Software for automatic coordination of protection devices in distribution system. IEEE Trans Power Deliv 2008; 23: 2241-2246.

[19] Dehghanian P, Fotuhi-Firuzabad M, Bagheri-Shouraki S, et al. Critical Component Identification in Reliability Centered Asset Management of Power Distribution Systems Via Fuzzy AHP. IEEE Syst J 2012; 6: 593-602.

[20] Zeng M, Cao F, Wei W, et al. Safety benefit evaluation of power supply enterprise based on entropy weight and AHP. Proc - Int Conf Manag Serv Sci MASS 2009 2009; 1-4.

[21] Ramirez-Rosado IJ, Dominguez-Navarro JA. Possibilistic Model Based on Fuzzy Sets for the Multiobjective Optimal Planning of Electric Power Distribution Networks. IEEE Trans Power Syst 2004; 19: 1801-1810.

[22] da Silva LGW, Fernandes Pereira RA, Abbad JR, et al. Optimised placement of control and protective devices in electric distribution systems through reactive tabu search algorithm. Electr Power Syst Res 2008; 78: 372-381.

[23] Tippachon W, Rerkpreedapong D. Multiobjective optimal placement of switches and protective devices in electric power distribution systems using ant colony optimization. Electr Power Syst Res 2009; 79: 1171-1178.

[24] Kumar Y, Das B, Sharma J. Multiobjective , multiconstraint service restoration of electric power distribution. IEEE Trans Power Deliv 2008; 23: 261-270.

[25] Leelaruji R, Vanfretti L. State-of-the-art in the industrial implementation of protective relay functions, communication mechanism and synchronized phasor capabilities for electric power systems protection. Renew Sustain Energy Rev 2012; 16: 4385-4395.

[26] Miñambres Argüelles JF, Arrieta MAZ, Domínguez JL, et al. A new method for decaying dc offset removal for digital protective relays. Electr Power Syst Res 2006; 76: 194-199.

[27] Horowitz SH, Phadke AG. Power System Relaying. Third Edit. 2008.

[28] Arismunandar A, Kuwahara S. Buku Pegangan Teknik Tenaga Listrik. 6th ed. Jakarta: Pradnya Paramita, 1993.

[29] Perçin S. Use of fuzzy AHP for evaluating the benefits of information-sharing decisions in a supply chain. J Enterp Inf Manag 2008; 21: 263-284. 
[30] Kwong CK, Bai H. Determining the importance weights for the customer requirements in QFD using a fuzzy AHF with an extent analysis approach. IIE Trans (Institute Ind Eng 2003; 35: 619-626.

[31] Kim I-D. Experiences and Future Prospects on the Digital Relay Application and Substation Automation. In: Transmission and Distribution Conference and Exhibition 2002: Asia Pacific. IEEE/PES. 2002, pp. 613-617. 